\title{
SUSCEPTIBILITY OF ANAEROBIC BACTERIA TO BETA-LACTAM ANTIBIOTICS AND BETA-LACTAMASE PRODUCTION
}

\author{
K. E. Aldridge, C. V. Sanders, A. C. Lewis, And R. L. Marier \\ Division of Infectious Diseases, Department of Medicine, Louisiana State University \\ Medical Center, 1542 Tulane Avenue, New Orleans, LA 70112
}

\begin{abstract}
SUMmaRY. We examined the susceptibility of various anaerobes to four beta-lactamase susceptible (ampicillin, amoxycillin, cyclacillin, and penicillin G) and two beta-lactamase resistant (moxalactam, and $\mathrm{N}$-F-thienamycin) beta-lactam antibiotics and measured beta-lactamase production. Members of the Bacteroides groups were most resistant to the six antibiotics. N-F-thienamycin was the most effective antimicrobial agent against all the test strains, moxalactam the next most effective, and penicillin $G$ the least. Beta-lactamase production was mainly confined to Bacteroides species. Cephalosporinase was the most common beta-lactamase produced; penicillinase was detected less often. About two thirds of the penicillin-resistant isolates produced cephalosporinase. N-F-thienamycin and moxalactam were the most active agents against those anaerobes that were resistant to many beta-lactam antibiotics.
\end{abstract}

\section{INTRODUCTION}

During the last two decades the clinical significance of anaerobic bacteria has been recognised. Infections of almost all body sites have been described and this has stimulated interest in the causative role of these organisms. The major factor contributing to this increased interest has been the increased ease with which the more common pathogenic anaerobes can be isolated and identified.

In the past, most reports have indicated that anaerobic isolates other than certain members of the Bacteroides fragilis group are, in general, susceptible to many antibiotics (Finegold and Hewitt, 1956; Ingham et al., 1968; Bodner et al., 1972; Martin, Gardner and Washington, 1972; Mitchell, 1973; Tally et al., 1975). However, more recent reports have indicated an increased resistance of anaerobes to certain antibiotics. Several studies have shown an increase in resistance of $B$. fragilis to tetracycline (Nastro and Finegold, 1972; Mitchell, 1973; Zabransky, Johnston and Hauser, 1973), minocycline and clindamycin (Staneck and Washington, 1974; Bawdon et al., 1979). Moreover, increased resistance to clindamycin and penicillin $\mathrm{G}$ has been noted among Clostridium spp. (Staneck and Washington, 1974; Marrie et al., 1981). This resistance can be the result of enzymatic inactivation of the antibiotic or decreased 
permeability of the cell to the antibiotic. New beta-lactamase resistant beta-lactam antibiotics have been developed to overcome the enzymatic types of resistance.

We examined the susceptibility of a wide variety of anaerobes to four beta-lactamase susceptible (ampicillin, amoxycillin, cyclacillin and penicillin $G$ ) and two beta-lactamase resistant (moxalactam and N-F-thienamycin) beta-lactam antibiotics, examined beta-lactamase production by resistant strains and attempted to correlate beta-lactamase production with resistance to penicillin $\mathrm{G}$.

\section{MATERIALS AND METHODS}

Antibiotics. The following antibiotic reference powders were provided by the manufacturers: ampicillin and amoxycillin (Beecham Laboratories, Bristol, TN.); cyclacillin (Wyeth Laboratories, Philadelphia, PA.); moxalactam and penicillin G (Eli Lilly Laboratories, Indianapolis, IN.); and N-formimidoyl thienamycin (Merck, Sharp and Dohme Laboratories, West Point, PA.). The powders were stored at $-20^{\circ} \mathrm{C}$ and working solutions were prepared and incorporated in media on the same day.

Organisms. One hundred and seventy nine strains of anaerobic bacteria from the stock collection of the Division of Infectious Diseases at LSU Medical Center were used. Each strain was grown on prereduced Brucella agar with vitamin $\mathrm{K}(0.1 \mu \mathrm{g} / \mathrm{ml})$ and sheep's blood $5 \%$. Growth was then transferred to thioglycollate broth by sterile cotton swabs and the turbidity adjusted to be equivalent to a 0.5 MacFarland standard.

MIC determinations. Serial twofold dilutions $(64-0.125 \mu \mathrm{g} / \mathrm{ml})$ of each antibiotic were prepared in Brucella agar with vitamin $\mathrm{K}(0 \cdot 1 \mu \mathrm{g} / \mathrm{ml})$ and sheep's blood $5 \%$. All plates were prereduced by holding them in anaerobic conditions overnight before seeding. Each organism was seeded in duplicate on to the plates by a Steers' replicator delivering $0.005 \mathrm{ml}$ of the thiogylcollate broth suspension on to the surface of each plate. The final inoculum was approximately $10^{5} \mathrm{cfu}$. The plates were placed in an anaerobic chamber at $35^{\circ} \mathrm{C}$ for $48 \mathrm{~h}$. The MIC was the lowest concentration of each antibiotic that inhibited visible growth of the organism (Greenberg et al., 1979).

Beta-lactamase assays. Each organism was tested by two methods:

1. A vial containing penicillin $\mathrm{G} 20 \times 10^{6}$ units was diluted to a concentration of $10^{6}$ units $/ \mathrm{ml}$ with phosphate buffer $(p \mathrm{H} \mathrm{7.0)}$ containing phenol red indicator $0.1 \%$. The $p \mathrm{H}$ of the solution was then raised to 8.5 with $0.1 \mathrm{~N} \mathrm{NaOH}$. Three drops of solution were added to each well of a microtitration tray and seeded with several colonies of an isolate. After incubation for $1 \mathrm{~h}$ at room temperature the presence of penicillinase was indicated by a change of colour from red-purple to yellow.

2. Chromogenic cephalosporin compound $87 / 312$ (Glaxo Inc., Ft. Lauderdale, FL) $5 \mathrm{mg}$ was dissolved in $1 \mathrm{ml}$ of dimethylsulfoxide and diluted with $19 \mathrm{ml}$ of phosphate buffer $(p \mathrm{H} \mathrm{7.0)}$. Three drops of this solution were added to each well in a microtitration tray and seeded with several colonies of an isolate. After incubation for $1 \mathrm{~h}$ at room temperature, the presence of cephalosporinase was indicated by a change of colour from yellow to rust-red.

\section{RESULTS}

\section{Sensitivity of anaerobes to beta-lactam antibiotics}

The results of the MIC determinations with six beta-lactam antibiotics are shown in table I. Bacteroides spp. were the most resistant group. We chose an MIC of 16 $\mu \mathrm{g} / \mathrm{ml}$ as the breakpoint for susceptibility. N-F-thienamycin was the most active antibiotic against the $\mathbf{4 0}$ test strains of the $B$. fragilis group (ss. fragilis, ss. vulgatus, ss. distasonis, and ss. thetaiotaomicron); $93 \%$ of the strains were inhibited by $4 \mu \mathrm{g} / \mathrm{ml}$ and 


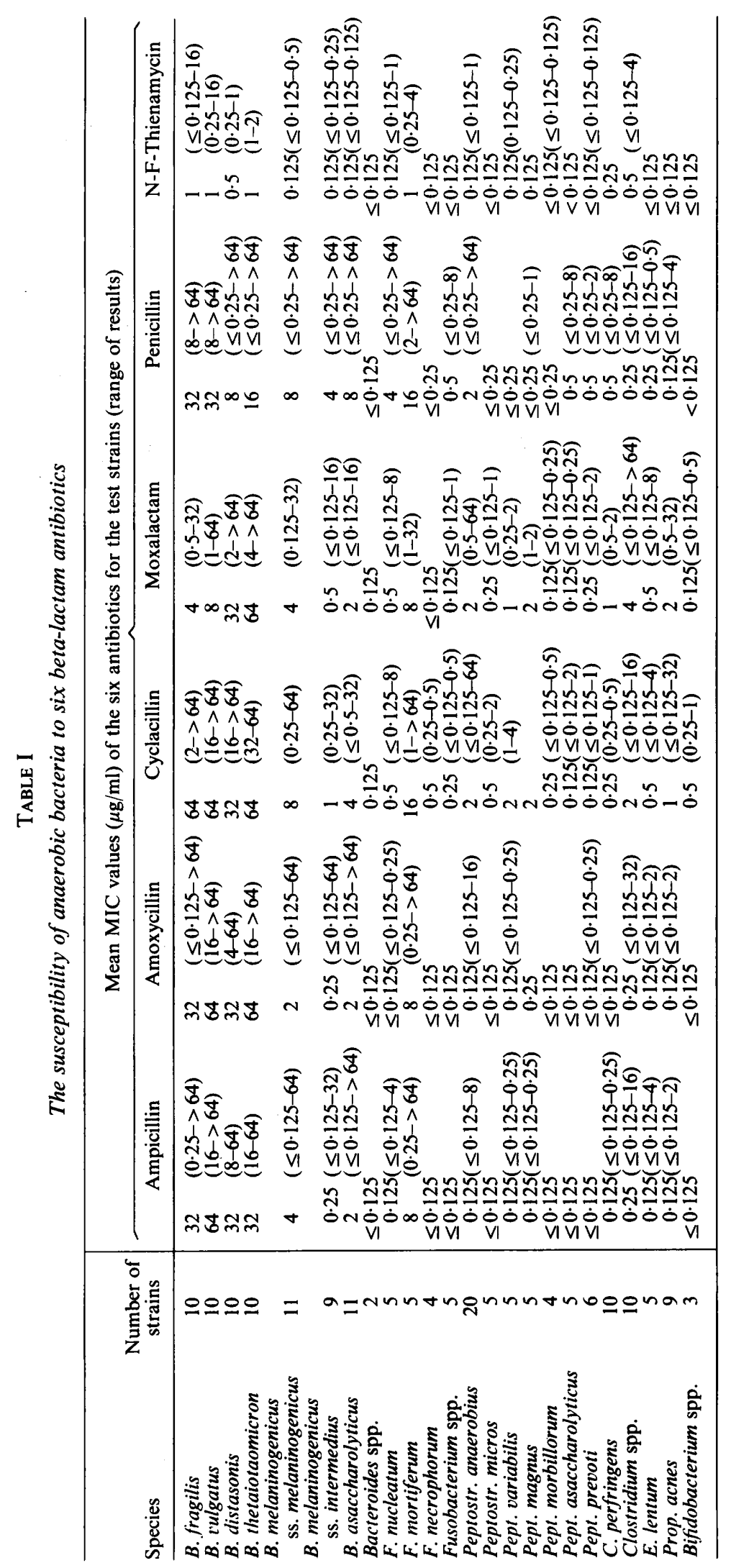


all of them by $16 \mu \mathrm{g} / \mathrm{ml}$. Moxalactam was the second most active antibiotic against this group; $63 \%$ of the strains were inhibited by $16 \mu \mathrm{g} / \mathrm{ml}$. The other group of Bacteroides strains that showed some resistance was the pigmented group- $B$. melaninogenicus ss. melaninogenicus and ss. intermedius and $B$. asaccharolyticus. $\mathrm{N}$-F-thienamycin and moxalactam were again the most active antibiotics against the 31 strains tested. N-F-thienamycin $0.5 \mu \mathrm{g} / \mathrm{ml}$ inhibited all the strains and with moxalactam $61 \%$ of the strains were inhibited by $4 \mu \mathrm{g} / \mathrm{ml}$ and all by $16 \mu \mathrm{g} / \mathrm{ml}$. Ampicillin, amoxycillin, cyclacillin and penicillin $\mathrm{G}$ were less effective; $16 \mu \mathrm{g} / \mathrm{ml}$ inhibited $71,77,81$ and $58 \%$ respectively of the strains.

In the Fusobacterium group, resistance to all the beta-lactams was low; strains of $F$. mortiferum were the most resistant and $F$. necrophorum the most susceptible. $\mathrm{N}-\mathrm{F}$-thienamycin $4 \mu \mathrm{g} / \mathrm{ml}$ inhibited all strains and moxalactam $16 \mu \mathrm{g} / \mathrm{ml}$ inhibited $95 \%$. Ampicillin, amoxycillin and cyclacillin $16 \mu \mathrm{g} / \mathrm{ml}$ inhibited $89 \%$ of the strains and penicillin G $16 \mu \mathrm{g} / \mathrm{ml}$ inhibited $85 \%$.

Ampicillin, amoxycillin, moxalactam and N-F-thienamycin inhibited all strains of Peptostreptococcus at concentrations $<16 \mu \mathrm{g} / \mathrm{ml}$, and cyclacillin and penicillin $\mathrm{G}$ inhibited 88 and $80 \%$ respectively. With all the antibiotics tested all strains of Peptococcus were sensitive to $<8 \mu \mathrm{g} / \mathrm{ml}$. Against the anaerobic gram-positive rods (Clostridium, Eubacterium, Propionibacterium and Bifidobacterium), N-F-thienamycin was the most effective antibiotic; all strains were inhibited by $16 \mu \mathrm{g} / \mathrm{ml}$. Amoxycillin, moxalactam and cyclacillin $16 \mu \mathrm{g} / \mathrm{ml}$ inhibited $>90 \%$ of strains.

\section{Beta-lactamase assays}

In most instances the beta-lactamase assays provided clear end points. Those that were not distinct were assessed by comparison with positive and negative controls.

Table II shows the results of the beta-lactamase assays. The Bacteroides strains gave the greatest number of positive results for both penicillinase and cephalosporinase. The only strains that produced penicillinase were Bacteroides spp. Cephalosporinase was the predominant beta-lactamase produced whereas penicillinase was often not produced. Cephalosporinase activity was strong in the producer strains; most positive results were evident within $15 \mathrm{~min}$. However, even when production was detected penicillinase activity was weaker; often incubation for $45 \mathrm{~min}$ or more was needed for a change in the colour of the reaction mixture to appear. Cephalosporinase was produced by $87 \%$ of $B$. fragilis and $42 \%$ of the pigmented Bacteroides strains but only $5 \%$ of $B$. fragilis and $16 \%$ of the pigmented strains produced penicillinase. No other anaerobic species produced penicillinase and only a few strains of Fusobacterium, Clostridium and Eubacterium produced cephalosporinase.

For comparison of beta-lactamase production with resistance to penicillin $\mathrm{G}$, organisms with MICs $\geq 16 \mu \mathrm{g} / \mathrm{ml}$ were considered resistant. Table III shows the number of penicillin G-resistant strains that produced beta-lactamases; $20 \%$ produced penicillinase only, $63 \%$ produced cephalosporinase only, and $20 \%$ produced both. The resistant Bacteroides strains were the most active producers of beta-lactamases. In the $B$. fragilis group, $85 \%$ of strains produced cephalosporinase but only $8 \%$ produced penicillinase whereas cephalosporinase was produced by $80 \%$ and penicillinase by $64 \%$ of the resistant pigmented strains. None of the remaining strains of penicillin-resistant anaerobes produced either penicillinase or cephalosporinase. 
TABLE II

Production of penicillinase and cephalosporinase

\begin{tabular}{|c|c|c|c|}
\hline \multirow[b]{2}{*}{ Species } & \multirow{2}{*}{$\begin{array}{l}\text { Number } \\
\text { of strains }\end{array}$} & \multicolumn{2}{|c|}{ Percentage of strains that produced } \\
\hline & & Penicillinase & Cephalosporinase \\
\hline $\begin{array}{l}\text { B. fragilis } \\
\text { B. tulgatus } \\
\text { B. distasonis } \\
\text { B. thetaiotaomicron } \\
\text { B. melaninogenicus ss. mel. } \\
\text { B. mel. ss. intermedius } \\
\text { B. asaccharolyticus } \\
\text { Bacteroides spp. } \\
\text { F. nucleatum } \\
\text { F. mortiferum } \\
\text { F. necrophorum } \\
\text { Fusobacterium spp. } \\
\text { Peptostr. anaerobius } \\
\text { Peptostr. micros } \\
\text { Pept. variabilis } \\
\text { Pept. magnus } \\
\text { Pept. morbillorum } \\
\text { Pept. asaccharolyticus } \\
\text { Pept. prevoti } \\
\text { C. perfringens } \\
\text { Clostridium } \text { spp. } \\
\text { E. lentum } \\
\text { Prop. acnes } \\
\text { Bifidobacterium spp. }\end{array}$ & $\begin{array}{r}10 \\
10 \\
10 \\
10 \\
11 \\
9 \\
11 \\
2 \\
5 \\
5 \\
4 \\
5 \\
20 \\
5 \\
5 \\
5 \\
4 \\
5 \\
6 \\
10 \\
10 \\
5 \\
9 \\
3\end{array}$ & $\begin{array}{r}10 \\
0 \\
10 \\
0 \\
36 \\
11 \\
36 \\
0 \\
0 \\
0 \\
0 \\
0 \\
0 \\
0 \\
0 \\
0 \\
0 \\
0 \\
0 \\
0 \\
0 \\
0 \\
0 \\
0\end{array}$ & $\begin{array}{r}70 \\
90 \\
90 \\
100 \\
55 \\
22 \\
36 \\
100 \\
0 \\
0 \\
0 \\
20 \\
0 \\
0 \\
0 \\
0 \\
0 \\
0 \\
0 \\
0 \\
10 \\
20 \\
0 \\
0\end{array}$ \\
\hline
\end{tabular}

TABLE III

Correlation between penicillin resistance $(M I C \geq 16 \mu \mathrm{g} / \mathrm{ml})$ and production of beta-lactamase

\begin{tabular}{|c|c|c|c|c|}
\hline \multirow[b]{2}{*}{ Species } & \multirow{2}{*}{$\begin{array}{l}\text { Number of } \\
\text { resistant } \\
\text { strains tested }\end{array}$} & \multicolumn{3}{|c|}{ Number (percent) of strains that produced } \\
\hline & & Penicillinase & Cephalosporinase & Both \\
\hline $\begin{array}{l}\text { B. fragilis } \\
\text { B. tulgatus } \\
\text { B. distasonis } \\
\text { B. thetaiotaomicron } \\
\text { B. melaninogenicus ss mel. } \\
\text { B. mel. } \text { ss. intermedius } \\
\text { B. assaccharolyticus } \\
\text { F. nucleatum } \\
\text { F. mortiferum } \\
\text { Peptostr. anaerobius } \\
\text { C. sphenoides } \\
\text { TOTAL }\end{array}$ & $\begin{array}{r}9 \\
8 \\
4 \\
6 \\
5 \\
3 \\
6 \\
1 \\
3 \\
8 \\
1 \\
54\end{array}$ & $\begin{array}{l}1(11) \\
0(0) \\
1(25) \\
0(0) \\
3(60) \\
1(33) \\
5(83) \\
0(0) \\
0(0) \\
0(0) \\
0(0) \\
11(20)\end{array}$ & $\begin{array}{l}6(67) \\
7(88) \\
4(100) \\
6(100) \\
5(100) \\
1(33) \\
5(83) \\
0(0) \\
0(0) \\
0(0) \\
0(0) \\
34(63)\end{array}$ & $\begin{array}{l}1(11) \\
0(0) \\
1(25) \\
0(0) \\
3(60) \\
1(33) \\
5(83) \\
0(0) \\
0(0) \\
0(0) \\
0(0) \\
11(20)\end{array}$ \\
\hline
\end{tabular}




\section{DisCUSSION}

The concept that penicillin has been and, for the most part, still is the most effective treatment for anaerobic infection has become firmly established among many clinicians. Reluctance by laboratories to do routine sensitivity tests of anaerobes is often based on this assumption, but the assumption is not always true. The Bacteroides group is the most antibiotic-resistant group of anaerobes and this resistance appears to have increased. Thadepalli, Gorbach and Bartlett (1977) reported that all $\boldsymbol{B}$. fragilis isolates were inhibited by penicillin at concentrations of $\leq 128 \mu \mathrm{g} / \mathrm{ml}$ and Monif et al. (1978) reported that $88 \%$ were inhibited by $\leq 100 \mu \mathrm{g} / \mathrm{ml}$; however, Marrie et al. (1981) reported only $68 \%$ sensitive to penicillin. Moreover, Ingham et al. (1968) found that all $B$. fragilis strains were inhibited by tetracycline at concentrations of $\leq 0.82 \mu \mathrm{g} / \mathrm{ml}$ but Martin et al. (1972) reported only $39 \%$ of their strains sensitive to $6.2 \mu \mathrm{g} / \mathrm{ml}$. Increased resistance of $C$. perfringens has also been reported. Dubois, Pechere and Turgeon (1978) reported that all strains were sensitive to penicillin $0.5 \mu \mathrm{g} / \mathrm{ml}$ whereas Marrie et al. (1981) found that inhibition of all strains was achieved only at $16 \mu \mathrm{g} / \mathrm{ml}$. We have also found resistant isolates among the $B$. melaninogenicus group in our hospital (unpublished data). New beta-lactam antibiotics have been developed to counteract this increasing resistance and studies with some of them are reported here.

The newer beta-lactams-N-F-thienamycin and moxalactam-showed significantly more in vitro activity than the other beta-lactams tested. N-F-thienamycin was the most effective of the beta-lactam antibiotics tested against beta-lactamase producers and nonproducers; $>90 \%$ of the $B$. fragilis group and all strains of other species were inhibited by $4 \mu \mathrm{g} / \mathrm{ml}$. Brown, Del Bene and Collins (1981) reported that B. fragilis ss. fragilis was very susceptible; studies with 100 strains gave a $\mathrm{MIC}_{90}$ of $0 \cdot 25$ $\mu \mathrm{g} / \mathrm{ml}$. Tally, Jacobus and Gorbach (1980) also found that it inhibited anaerobic cocci and Clostridium spp. at 0.25 and $4 \mu \mathrm{g} / \mathrm{ml}$ respectively.

Our results with moxalactam were similar to those reported by Jorgensen, Crawford and Alexander (1980) and Brown et al. (1981) except that several strains of Bacteroides in our series had MICs $>64 \mu \mathrm{g} / \mathrm{ml}$. Most strains of Fusobacterium spp. were inhibited by $8 \mu \mathrm{g} / \mathrm{ml}$. Our results with ampicillin and cyclacillin agree with those of Bach and Thadepalli (1980); these two antibiotics were less effective than penicillin $\mathrm{G}$ against $\boldsymbol{B}$. fragilis and most other Bacteroides. We found, however, that cyclacillin was more effective than penicillin $\mathrm{G}$ and ampicillin against the pigmented Bacteroides, and against the Fusobacterium spp. ampicillin was slightly more effective than cyclacillin and penicillin G. Amoxycillin did not have significantly greater in vitro activity than ampicillin, cyclacillin or penicillin $\mathrm{G}$.

The beta-lactamases of many aerobic and facultatively anaerobic organisms have been classified and characterised. Some of the enzymes have more than one substrate and can be controlled by either chromosomal or plasmid genes (Sykes and Matthew, 1976). Beta-lactamases of anaerobes are less defined. Our tests detected the presence in suspensions of the test strains of enzymes that would cleave the beta-lactam ring of the penicillin or cephalosporin substrate. Thus, we could detect penicillinases and cephalosporinases. Our results indicate that beta-lactamase production is confined mainly to the Bacteroides spp. Cephalosporinase was the most common enzyme; penicillinase was detected less frequently. 
By our criterion of penicillin $\mathrm{G}$ resistance $(\mathrm{MIC} \geq 16 \mu \mathrm{g} / \mathrm{ml}$ ), resistance and beta-lactamase production correlate poorly. About two thirds of the penicillin-resistant isolates produced cephalosporinase-three times more than produced penicillinase. Penicillinase and cephalosporinase activities were detected in only $20 \%$ of the resistant isolates and $80 \%$ of the penicillin-resistant strains showed no beta-lactamase activity against penicillin, which indicates that there may be other mechanisms of penicillin resistance. In penicillin-susceptible isolates penicillinase activity was detected in only one $(0.8 \%)$ strain of B. melaninogenicus but $13 \%$ of susceptible strains produced cephalosporinase. Gill, Manning and Ingalls (1981) reported that $3 \%$ of penicillin G-sensitive (MIC $\leq 0.05$ ) strains of Staphylococcus aureus produced betalactamase.

Others have found that resistance to beta-lactam antibiotics among anaerobes and beta-lactamase production are not necessarily synonymous (Brown et al., 1981; Gaby, Sutter and Finegold, 1981). An intrinsic resistance that may be due to a permeability barrier for the antibiotic or to crypticity of the beta-lactamase, or both, may be involved (Brown et al., 1981). Alternatively, our assay may not be sufficiently sensitive to detect low levels of beta-lactamase production. Others have shown that certain organisms must be disrupted before beta-lactamase can be detected (Nord, Dornbusch and Olsson, 1980; Brown et al., 1981). Additionally Weinrich and Del Bene (1976) found no specific pattern of beta-lactamase production and resistance to penicillin in $B$. fragilis.

The present study has drawn attention to the high incidence of resistance to beta-lactams in anaerobes. Two new agents, N-F-thienamycin and moxalactam, were the most active against resistant strains. Ampicillin, amoxycillin, cyclacillin and penicillin $\mathrm{G}$ were ineffective against most Bacteroides and Fusobacterium strains. Our results agree with reports that Bacteroides and Fusobacterium spp. have become more resistant to many of the commonly used beta-lactam antibiotics (Sutter and Finegold, 1976; Appelbaum and Chatterton, 1978; Finegold, 1979; Sanders and Lewis, 1980; Gill et al., 1981). Our experiments have also shown that beta-lactamase production does not necessarily correlate with beta-lactam resistance and indicate that standardised methods for sensitivity testing of anaerobes are necessary.

We thank Jan Mitchell and Tina Moustoukas for technical assistance and Rose Decker for secretarial assistance.

\section{REFERENCES}

Appelbaum, P. C., and Chatterton, S. A. 1978. Susceptibility of anaerobic bacteria to ten antimicrobial agents. Antimicrobial Agents and Chemotherapy, 14, 371-376.

BaCH, V. T., AND Thadeppalli, H. 1980. Susceptibility of anaerobic bacteria in vitro to 23 antimicrobial agents. Chemotherapy, 26, 344-352.

Bawdon, R. E., Rozmiej, E., Palchaudhuri, S. and Krakowiak, J. 1979. Variability in the susceptibility pattern of Bacteroides fragilis in four Detroit area hospitals. Antimicrobial Agents and Chemotherapy, 16, 664-666.

Bodner, S. J., Koenig, M. G., Treanor, L. L., and Goodman, J. S. 1972. Antibiotic susceptibility testing of Bacteroides. Antimicrobial Agents and Chemotherapy, 2, 57-60.

Brown, J. E., Del Bene, V. E., AND Collins, C. D. 1981. In vitro activity of N-formimidoylthienamycin, moxalactam, and other new beta-lactam agents against Bacteroides fragilis: contribution of beta-lactamase to resistance. Antimicrobial Agents and Chemotherapy, 19, 248-252. 
Dubois, J., PeChere, J. C., AND TuRgeon, P. 1978. Activity of ten antimicrobial agents against anaerobic bacteria. Journal of Antimicrobial Chemotherapy, 4, 329-334.

FineGOLD, S. M. 1979. Anaerobic infections. Archives of Internal Medicine, 129, 144-145.

FINEGOLD, S. M., AND HEWITT, W. L. 1956. Antibiotic sensitivity pattern of Bacteroides species. In Antibiotics annual, edited by $\mathrm{H}$. Welch and F. Marti-Ibanez, Medical Encyclopedia, Inc., New York, pp. 794-801.

GABAY, E. L., SUtTER, V. C., AND Finegold, S. M. 1981. Beta-lactamase testing in Bacteroides. American Society for Microbiology Annual Meeting, p. 12.

Gill, V. J., Manning, C. B., AND Ingalls, C. M. 1981. Correlation of penicillin minimum inhibitory concentration and penicillin zone edge appearance with staphylococcal beta-lactamase production. Journal of Clinical Microbiology, 14, 437-440.

Greenberg, R. N., Scalcini, M. C., Sanders, C. V. AND LeWIS, A. C. 1979. Cefamandole therapy in anaerobic infections. Antimicrobial Agents and Chemotherapy, 15, 337-341.

Ingham, H. R., Selkon, J. B., Codd, A. A., AND Hale, J. H. 1968. A study in vitro of the sensitivity to antibiotics of Bacteroides fragilis. Journal of Clinical Pathology, 21, 432-436.

JoRgenSEN, J. H., CRAWford, S. A., AND AleXANDER, G. A. 1980. Comparison of moxalactam (LY127935) and cefotaxime against anaerobic bacteria. Antimicrobial Agents and Chemotherapy, 17, 901-904.

Marrie, T. J., Haldane, E. V., Swantee, C. A., AND Kerr, E. A. 1981. Susceptibility of anaerobic bacteria to nine antimicrobial agents and demonstration of decreased susceptibility of Clostridum perfringens to penicillin. Antimicrobial Agents and Chemotherapy, 19, $51-55$.

Martin, W. J., Gardner, M., and Washington, J. A. 1972. In vitro antimicrobial susceptibility of anaerobic bacteria isolated from clinical specimens. Antimicrobial Agents and Chemotherapy, 1, 148-158.

MitChell, A. A. B. 1973. Incidence and isolation of Bacteroides species from clinical material and their sensitivity to antibiotics. Journal of Clinical Pathology, 26, 738-741.

Monif, G. R. G., Clark, P. R., Shuster, J. J., and Baer, H. 1978. Susceptibility of the anerobic bacteria, group D streptococci, Enterobacteriaceae, and Pseudomonas to semisynthetic pencillins: carbenicillin, piperacillin, and ticarcillin. Antimicrobial Agents and Chemotherapy, 14, 643-649.

NASTRO, L. J., AND FineGold, S. M. 1972. Bactericidal activity of five antimicrobial agents against Bacteroides fragilis. Journal of Infectious Diseases, 126, 104-107.

Nord, C. E., DoRnbusCh, K., AND Olsson, B. 1980. Studies on beta-lactamase in Bacteroides fragilis. Infection, 8 (Suppl. 2), 167-170.

SANDERS, C. V., AND LewIS, A. C. 1980. Changing trends in the antimicrobial susceptibility pattern of anaerobic bacteria. In Anaerobic bacteria; selected topics, edited by D.W. Lambe, R.J. Genco, and K.J. Mayberry-Carson, Plenum Press, New York, pp. 61-68.

StANECK, J. L., AND WaShington, J. A. 1974. Antimicrobial susceptibilities of anaerobic bacteria: recent clinical isolates. Antimicrobial Agents and Chemotherapy, 6, 311-315.

SutTeR, V. L., AND FINEgold, S. M. 1976. Susceptibility of anaerobic bacteria to 23 antimicrobial agents. Antimicrobial Agents and Chemotherapy, 10, 736-752.

SyKES, R. B., AND MATTHEW, M. 1976. The beta-lactamases of gram-negative bacteria and their role in resistance to beta-lactam antibiotics. Journal of Antimicrobial Chemotherapy, 2, 115-157.

Tally, F. P., Jacobus, N. V., Bartlett, J. G., and Gorbach, S. L. 1975. In vitro activity of penicillins against anaerobes. Antimicrobial Agents and Chemotherapy, 7, 413-414.

TALLY, F. P., JaCOBUS, N. V., AND GORBaCH, S. L. 1980. In vitro activity of N-Formimidoyl Thienamycin (MK0787). Antimicrobial Agents and Chemotherapy, 18, 642-644.

Thadepalli, H., Gorbach, S. L., AND Bartlett, J. G. 1977. Apparent failure of chloramphenicol in the treatment of anaerobic infections. Current Therapeutic Research, 22, $421-426$.

WeINRICH, A. E., AND Del BeNe, V. E. 1976. Beta-lactamase activity in anaerobic bacteria. Antimicrobial Agents and Chemotherapy, 10, 106-111.

Zabransky, R. J., Johnston, J. A., Hauser, K. J. 1973. Bacteriostatic and bactericidal activities of various antibiotics against Bacteroides fragilis. Antimicrobial Agents and Chemotherapy, 3, 152-156. 